\title{
ALUMINUM SUBSTITUTION IN GOETHITE IN LAKE ORE
}

\author{
LIISA CARLSON
}

\begin{abstract}
CARLSON, LIISA, 1995: Aluminum substitution in goethite in lake ore. Bull. Geol. Soc. Finland 67, Part 1, 19-28.

The extent of substitution of $\mathrm{Fe}$ by $\mathrm{Al}$ in goethite in 32 lake ore samples collected from 11 lakes in Finland varied between 0 and 23 mol- $\%$. The data indicated a negative relationship between $\mathrm{Al}$-substitution and the particle size of lake ore. Differences in the Al-substitution were apparent between sampling sites, suggesting that kinetic and environmental variation in lake ore formation influences the substitution. Non-substituted goethite is formed in coarse-grained sediments with locally high concentrations of $\mathrm{Fe}$ due to iron-rich springs. Unit cell edge lengths and volumes of goethite varied as function of Al-subsitution but deviated from the Vegard relationship towards higher values.
\end{abstract}

Key words: goethite, iron, aluminum, substitution, unit cell, lake ores, Finland.

Liisa Calson: Pietarinkatu 10 B 16, Fin-00140 Helsinki

\section{INTRODUCTION}

Aluminum can substitute for up to one third of iron in goethite. In soil goethites large variation in Alsubstitution reflects different pedogenic environments. Strong weathering conditions in non-hydromorphic soils promote $\mathrm{Al}$ substitution in goethite, compared with hydromorphic environments where weathering is less severe (Fitzpatrick and Schwertmann, 1982). The degree of Al substitution reflects the activity of soluble aluminum associated with goethite crystal development and, therefore, is influenced by $\mathrm{pH}$ and Si concentration (Schwertmann and Taylor, 1989).

Iron oxides have been characterized from diverse environments: natural cold springs (Carlson and Schwertmann, 1981), groundwater treatment plants (Hatva et al., 1985), podzol B-horizons (Jauhiainen, 1969), bands in gravel and sand (Koljonen et al., 1976; Carlson et al., 1977), concretions around root channels (Alhonen et al., 1975), and lake ores. In springs and water treatment plants the rate of iron oxidation is relatively high and mainly ferrihydrite is formed (Carlson and Schwertmann, 1987). Ochreous bands in gravel and sand, formed in the capillary fringe zone, contain both lepidocrocite and goethite (Koljonen et al., 1976), as also reported for root concretions (Schwertmann and Fitzpatrick, 1977). Lake ores contain mainly goethite. Some lake ores also contain some ferrihydrite which can, however, be easily removed. Therefore, lake ores are well suited for the determination of $\mathrm{Al}$ substitution in goethites formed under the climatic conditions prevailing in Finland.

Nodular Fe-Mn concretions also occur in many diverse environments. Deep-sea manganese nodules contain appreciable concentrations of metals such as $\mathrm{Ni}, \mathrm{Cu}, \mathrm{Zn}$, and $\mathrm{Co}$. Shallow sea Fe-Mn concretions show a higher rate of accumulation (more than 10.000 times), higher Fe-Mn ratios, and about 2 orders of magnitude lower content of trace metals than deep-sea manganese nodules (Moenke-Blankenburg et al., 1989). Lake ores, on an average, have slightly higher $\mathrm{Fe}-\mathrm{Mn}$ ratios, higher rate of formation, and lower heavy metal content than the shallow sea concretions. In both lake ores and shallow sea concretions the Fe-Mn 
ratios vary considerably, or Mn-rich layers alternate with Fe-rich layers (Vaasjoki, 1956; Winterhalter and Siivola, 1967). Concretionary $\mathrm{Fe}-\mathrm{Mn}$ oxide accumulations are also found in streams (Nowlan et al., 1983) and soils (Taylor and Schwertmann, 1974).

Concretions from shallow sea and lake bottoms are spherical or discoidal, or form continuous crusts. Many descriptive characterizations have been used (e.g., buckshot, bean, pea, dried prune, potato) for more or less irregular spherical concretions (Aschan, 1908; Moore, 1910; Schoettle and Friedman, 1971). They have also been called pisolitic or oolitic (Strakhov, 1966; Halbach, 1976). Morphologically, discoidal forms have been compared to buttons, pennies, dried apricots, biscuits, saucers, pancakes, cakes and shields (Aschan, 1908; Moore, 1910; Aarnio, 1917; Schoettle and Friedman, 1971; Burns and Brown, 1972; Suess and Djafari, 1977).

In this study, the terms spherical, discoidal, and crust ore are used. With lake ores formed in shallow parts of the lakes (depths down to a few meters), the size decreases with depth: crust ore is found closest to the shore, discoidal ore at medium depths, and spherical ore farthest away and within the uppermost $5-10 \mathrm{~cm}$ of bottom sediment (Strakhov, 1966; Halbach, 1976). There is some overlap in the formation zones of the different types and sometimes even all three types can be sampled in one site. Often only concretional forms are found, or, less frequently, solely small spherical pisoliths. Aarnio (1917) speculated that thick, shapeless lake ore (bar ore) is formed where Fe-bearing spring oozes evenly through the bottom sediment. Where it only can use root channels to reach the lake bottom, concretions are formed: spherical (buckshot and pea ore) if there are plenty of channels and a thin layer of gyttja, and discoidal (shield ore) if the channels are fewer and the layer of gyttja is thick.

Schwertmann et al. (1987) studied Alsubstitution in lake-ore goethites from two Finnish lakes. Goethites from thick crust ore formed on gravelly bottom sediment were non-substituted, whereas nodular (spherical and discoidal) lake ores formed on silty-clayey bottom sediment showed Al-substitution of 7.2 - 8.6 mol- $\%$. The crust ores also contained a high amount of ferrihydrite, and it was concluded that the rate of lake-ore formation was relatively high. The nodular lake ores formed in and on finer-grained bottom sediment showed better crystallinity of their goethites and contained no ferrihydrite suggesting that they were formed slowly. The main reason for the difference in Al-substitution of their goethites was thought to be the difference in the availability of $\mathrm{Al}$ from the bottom sediments: clay minerals with high Al supply versus coarse grained quartz and feldspar with low Al supply.

In the present study lake ore samples were collected and Al-substitution of the goethite fractions were determined. Because the environment of lake ore formation influences nodular size and form, sampling was carried out in an effort to establish if there is a difference in Al-substitution of goethites from different size classes of lake ores and what its significance might be.

\section{MATERIALS AND METHODS}

For this work, lake ore and bottom sediment were sampled from 14 lakes in southern, central, and eastern Finland. Those rich in manganese or ferrihydrite $(\mathrm{Feo} / \mathrm{Fed}>0.21)$ were excluded. Two goethite-rich reference samples described by Schwertmann et al. (1987) and four samples from the courtesy of T. Koljonen (Geological Survey of Finland) were included in this study. Most of the samples contained spherical and discoidal concretions but crust ore was also included. Where a variety of sizes (and shapes) were available, subsampling was done by handpicking. Thus, a total of 32 lake ore samples from 15 sampling sites in 11 lakes were examined (Table 1). Grain size distribution was determined by sieving for ten bottom sediment samples.

The samples were gently crushed in an agate mortar. To exclude poorly ordered Fe- and Alcompounds the samples were first extracted with acid ammonium oxalate (Schwertmann, 1964). Fe and $\mathrm{Al}$ concentrations in the supernatant were 
Table 1. Sampling sites and lake ore types.

\begin{tabular}{|c|c|c|c|c|c|c|c|c|}
\hline \multirow{2}{*}{\multicolumn{2}{|c|}{$\begin{array}{l}\text { Sample Lake } \\
\text { No }\end{array}$}} & Coordinates & \multirow{2}{*}{$\begin{array}{l}\text { Depth } \\
\mathrm{m}\end{array}$} & \multirow{2}{*}{$\begin{array}{l}\text { Lake-ore } \\
\text { types }^{a}\end{array}$} & \multirow{2}{*}{$\begin{array}{l}\text { Water } \\
\mathrm{pH}\end{array}$} & \multicolumn{3}{|c|}{ Bottom sediment ${ }^{b}$} \\
\hline & & $\mathrm{N} \quad \mathrm{E}$ & & & & $\mathrm{cl} / \mathrm{si}^{\varsigma}$ & $\mathrm{sa} \%$ & gr\% \\
\hline 101 & Liesjärvi & $60^{\circ} 41^{\prime} 23^{\circ} 55^{\prime}$ & 1.0 & $\mathrm{sp}$, di & 8.8 & 6 & 94 & 0 \\
\hline 102 & Salkolanjärvi & $60^{\circ} 38^{\prime} 23^{\circ} 52^{\prime}$ & 1.5 & $\mathrm{di}$ & 6.1 & 13 & 87 & 0 \\
\hline 103 & Vuotinainen & $60^{\circ} 37^{\prime} 24^{\circ} 04^{\prime}$ & 0.5 & di & 5.8 & 0 & 100 & 0 \\
\hline 107 & Jääsjärvi & $61^{\circ} 36^{\prime} 26^{\circ} 04^{\prime}$ & 1.5 & $\mathrm{sp}$ & 6.3 & 30 & 70 & 0 \\
\hline $109 \mathrm{~A}$ & Tohmajärvi & $62^{\circ} 11^{\prime} 30^{\circ} 23^{\prime}$ & 0.4 & sp, di & 7.0 & 0 & 100 & 0 \\
\hline 109B & Tohmajärvi & $62^{\circ} 11^{\prime} 30^{\circ} 23^{\prime}$ & 0.5 & $\mathrm{sp}$, di & 7.0 & 0 & 100 & 0 \\
\hline $109 \mathrm{C}$ & Tohmajärvi & $62^{\circ} 11^{\prime} 30^{\circ} 23^{\prime}$ & 0.6 & di & 7.0 & 0 & 100 & 0 \\
\hline 111 & Pyhtäänjärvi & $62^{\circ} 19^{\prime} 26^{\circ} 02^{\prime}$ & 1.4 & $\mathrm{sp}, \mathrm{cr}$ & 6.5 & 20 & 80 & 0 \\
\hline 114 & Koitere & $63^{\circ} 00^{\prime} 30^{\circ} 47^{\prime}$ & $4-5$ & $\mathrm{cr}$ & n.d. & n.d. & & \\
\hline $39 D$ & Murtojärvi & $62^{\circ} 27^{\prime} 30^{\circ} 09^{\prime}$ & 1.2 & sp, di, cr & 6.7 & 1 & 58 & 41 \\
\hline $46 \mathrm{C}$ & Enovesi & $61^{\circ} 29^{\prime} 25^{\circ} 54^{\prime}$ & 0.8 & $\mathrm{sp}, \mathrm{di}, \mathrm{cr}$ & 6.9 & 91 & 9 & 0 \\
\hline K84 & Petäjävesi & $62^{\circ} 15^{\prime} 25^{\circ} 10^{\prime}$ & 1.0 & $\mathrm{sp}, \mathrm{cr}$ & n.d. & n.d. & & \\
\hline K87 & Petäjävesi & $62^{\circ} 15^{\prime} 25^{\circ} 10^{\prime}$ & 2.0 & $\mathrm{sp}$, di & n.d. & n.d. & & \\
\hline $49 C$ & Piispajärvi & $65^{\circ} 34^{\prime} 29^{\circ} 04^{\prime}$ & 1.0 & $\mathrm{sp}$, di & n.d. & n.d. & & \\
\hline 49D & Piispajärvi & $65^{\circ} 34^{\prime} 29^{\circ} 04^{\prime}$ & 1.5 & $\mathrm{sp}, \mathrm{di}$ & n.d. & n.d. & & \\
\hline $\begin{array}{l}\text { a, sp, } \\
\text { b, cl/s } \\
\text { n.d., r }\end{array}$ & $\begin{array}{l}\text { pherical; di, di } \\
\text { fraction }<62 \\
\text { t determined. }\end{array}$ & $\begin{array}{l}\text { scoidal; cr, cru } \\
\text { } \text { m; sa, fractior }\end{array}$ & $-2 \mathrm{mr}$ & ction $>2$ & & & & \\
\hline
\end{tabular}

generally low. $\mathrm{Fe}$ and $\mathrm{Al}$ in the oxalate-treated residue were extracted using the dithionitecitrate-bicarbonate method of Mehra and Jackson (1960) and determined using a Jobin Yvon 70+ inductively-coupled plasma emission spectrometer. The dithionite-citrate-bicarbonate method selectively dissolves oxidic Fe compounds, and thus only Al bound in Fe oxides, leaving the silicate minerals intact.

The effect of Al-substitution on the unit cell edge lengths of goethite was determined on the basis of step-scanned X-ray diffraction (XRD) patterns using $\operatorname{CoK} \alpha$ radiation and a Philips PW 1050 vertical goniometer equipped with a graphite reflected-beam monochromator. Step size was $0.05^{\circ} 2 \Theta$ and counting time $20 \mathrm{~s} / \mathrm{step}$. All specimens were step-scanned from 10 to $80^{\circ} 2 \Theta$. Back-filled powder mounts were used with $\mathrm{Si}$ as internal standard. The digitized scans were fitted with the FIT curve program of Janik and Raupach (1977) as modified by H. Stanjek (unpublished). Unit-cell edge lengths were calculated with the program Gitter (W. Hummel, unpublished) using six $\tan \Theta$ weighted reflections $(110,130,111$, 221, 151, and 002).

\section{RESULTS AND DISCUSSION}

\section{Al-substitution as determined chemically}

The lake ore samples contain 30-51\% (wt/wt) iron (Table 2), indicating that they were relatively pure iron oxides. The nodular forms were mostly concentric around a nucleus such as a sand particle. A small amount of fine-grained material such as clay particles and organic detritus was probably trapped during the precipitation of iron oxide. The total carbon content of lake ores from Lake Murtojärvi and Lake Enovesi was 0.4-1.6 \% (wt/wt) (Schwertmann et al., 1987). The aluminum content of lake ores varies from 0.0 to $5.7 \%$ (wt/wt) (Table 2) which is equivalent to 0.1 to 23 mol- $\%$ substitution. 
Table 2. Dithionite-soluble Fe and Al in different type and size classes of lake ores.

\begin{tabular}{|c|c|c|c|c|c|}
\hline Sample No & Type $^{a}$ & Size $^{b} \mathrm{~mm}$ & $\mathrm{Fe}_{\mathrm{d}-\mathrm{o}} \%$ & $\mathrm{Al}_{\mathrm{d}-0} \%$ & Al mol-\% \\
\hline 101 & $\begin{array}{l}\mathrm{sp} \\
\mathrm{sp} \\
\mathrm{di} \\
\mathrm{di}\end{array}$ & $\begin{array}{l}1-2 \\
3-5 \\
5-7 \\
10-13\end{array}$ & $\begin{array}{l}43.72 \\
46.85 \\
43.90 \\
43.61\end{array}$ & $\begin{array}{l}3.64 \\
2.27 \\
2.10 \\
1.51\end{array}$ & $\begin{array}{r}14.65 \\
9.13 \\
9.01 \\
6.69\end{array}$ \\
\hline 102 & di & $6-9$ & 38.60 & 1.84 & 8.98 \\
\hline 103 & di & 12 & 41.51 & 1.69 & 7.77 \\
\hline 107 & $\mathrm{sp}$ & $1-3$ & 40.02 & 5.67 & 22.67 \\
\hline $109 \mathrm{~A}$ & $\begin{array}{l}\mathrm{sp} \\
\mathrm{di}\end{array}$ & $\begin{array}{c}4 \\
6-8\end{array}$ & $\begin{array}{l}45.03 \\
41.34\end{array}$ & $\begin{array}{l}0.84 \\
0.64\end{array}$ & $\begin{array}{l}3.72 \\
3.12\end{array}$ \\
\hline 109B & $\begin{array}{l}\mathrm{sp} \\
\mathrm{di} \\
\mathrm{cr}\end{array}$ & $\begin{array}{l}2-5 \\
6-7\end{array}$ & $\begin{array}{l}47.88 \\
48.21 \\
31.86\end{array}$ & $\begin{array}{l}0.73 \\
0.94 \\
0.19\end{array}$ & $\begin{array}{l}3.06 \\
3.87 \\
1.23\end{array}$ \\
\hline $109 C$ & di & $5-7$ & 35.10 & 0.72 & 4.05 \\
\hline 111 & $\begin{array}{l}\mathrm{sp} \\
\mathrm{cr}\end{array}$ & $2-7$ & $\begin{array}{l}46.43 \\
44.74\end{array}$ & $\begin{array}{l}1.34 \\
0.28\end{array}$ & $\begin{array}{l}5.63 \\
1.28\end{array}$ \\
\hline 114 & $\mathrm{cr}$ & & 29.28 & 0.41 & 2.84 \\
\hline 39D & $\begin{array}{l}\mathrm{sp} \\
\mathrm{di}\end{array}$ & $\begin{array}{l}5-8 \\
12-14\end{array}$ & $\begin{array}{l}39.43 \\
37.32\end{array}$ & $\begin{array}{l}0.021 \\
0.046\end{array}$ & $\begin{array}{l}0.11 \\
0.25\end{array}$ \\
\hline $46 C$ & $\begin{array}{l}\mathrm{sp} \\
\mathrm{sp} \\
\mathrm{di}\end{array}$ & $\begin{array}{l}1-3 \\
5-8 \\
4-7\end{array}$ & $\begin{array}{l}43.68 \\
38.79 \\
50.05\end{array}$ & $\begin{array}{l}2.775 \\
1.52 \\
2.57\end{array}$ & $\begin{array}{r}11.62 \\
7.48 \\
9.62\end{array}$ \\
\hline K84 & $\begin{array}{l}\mathrm{sp} \\
\mathrm{sp} \\
\mathrm{sp} \\
\mathrm{cr}\end{array}$ & $\begin{array}{l}1-2 \\
3-6 \\
6-10\end{array}$ & $\begin{array}{l}43.11 \\
46.34 \\
50.69 \\
49.53\end{array}$ & $\begin{array}{l}4.67 \\
2.35 \\
2.11 \\
1.94\end{array}$ & $\begin{array}{r}18.31 \\
9.50 \\
7.93 \\
7.50\end{array}$ \\
\hline K87 & $\begin{array}{l}\mathrm{sp} \\
\mathrm{sp} \\
\mathrm{di}\end{array}$ & $\begin{array}{l}1-3 \\
3-6 \\
12-14\end{array}$ & $\begin{array}{l}42.66 \\
42.42 \\
39.30\end{array}$ & $\begin{array}{l}4.35 \\
2.55 \\
1.33\end{array}$ & $\begin{array}{r}17.44 \\
11.06 \\
6.56\end{array}$ \\
\hline $49 C$ & $\begin{array}{l}\mathrm{sp} \\
\mathrm{di}\end{array}$ & $\begin{array}{l}3-5 \\
6-8\end{array}$ & $\begin{array}{l}47.52 \\
44.50\end{array}$ & $\begin{array}{l}2.66 \\
2.31\end{array}$ & $\begin{array}{r}10.38 \\
9.71\end{array}$ \\
\hline 49D & $\begin{array}{l}\text { sp } \\
\text { di }\end{array}$ & $\begin{array}{l}2-3 \\
5-7\end{array}$ & $\begin{array}{l}37.52 \\
43.30\end{array}$ & $\begin{array}{l}3.17 \\
3.05\end{array}$ & $\begin{array}{l}14.88 \\
12.71\end{array}$ \\
\hline \multicolumn{6}{|c|}{$\begin{array}{l}\text { a, sp, spherical; di, discoidal; cr, crust ore } \\
\text { b, diameter of spherical lake ores; } \\
\text { diameter of discoidal lake ore, thickness 1-4 mm. }\end{array}$} \\
\hline
\end{tabular}


There was an inverse correlation between aluminum substitution and lake-ore size (Table 2), also within one sampling site (e.g., sites 101, 46C, K84, K87, and 49C,D). The smallest pisoliths (1 - 2 $\mathrm{mm}$ or $1-3 \mathrm{~mm}$ ) show highest substitution. The highest substitution was found in samples from site 107 where only few, small spherical concretions were found in the uppermost silty sand sediment (Table 1).

According to Strakhov (1966), in shallow depths of small lakes, lake ore particle size decreses with increasing depth of water and also of bottom sediment. The reason for this could be that with increasing depth and within the sediment the conditions are less oxidizing and thus the rate of formation and the particle size are reduced. Another explanation for higher substitution, suggested by Schwertmann et al. (1987), is the availability of aluminum in the environment. In laboratory experiments clay minerals have been found to supply Al to developing goethite (Schwertmann, 1988). In lakes, bottom sediments normally become finer with depth but there are differences between lakes. In Lake Tohmajärvi (site 109), only medium sand was found in the ore-bearing zone, and there was little difference in $\mathrm{Al}$ substitution between the different subsamples (Table 2). The coarsest bottom sediment and highest rate of Fe supply, according to high proportions of ferrihydrite (Feo/Fed 0.12 - 0.46; Schwertmann et al., 1987) in most ores examined, were found in Lake Murtojärvi (site 39D). Even the smallest ores which are formed in greater depths but in coarse sediment (Table 1) than the thick crust ores showed no Al-substitution in their goethite fractions. Highly substituted goethites are formed where the rate of Fe supply and of lake ore formation probably are low, and clay minerals and other Al sources are present. In this environment, concentrations of dissolved $\mathrm{Fe}$ and $\mathrm{Al}$, and the $\mathrm{Fe}$ $\mathrm{Al}$ ratio in pore solution are low. Differences within one sampling site (the highest measured substitution more than twice that of the lowest, e.g., sites 101, $\mathrm{K} 84, \mathrm{~K} 87$ ) could be due to formation in different microenvironments, on the bottom sediment vs. within it or at different depths, affecting both the rate of oxidation and the availability of $\mathrm{Al}$.
The influence of $\mathrm{Al}$-substitution on the unit cell edge lenghts of goethite

The $\mathrm{Al}^{3+}$ ion is smaller than the $\mathrm{Fe}^{3+}$ ion by $15 \%$. The unit cell of diaspore $(\alpha-\mathrm{AlOOH})$ is smaller by $15 \%$ (a, $4.396 \AA$; $, 2,9.426 \AA$;, $2.844 \AA$; V, $117.85 \AA^{3}$; JCPDS card 5-355) than the unit cell of goethite $(\alpha-\mathrm{FeOOH})(\underline{\mathrm{a}}, 4.606 \AA$; $\underline{\mathrm{b}}, 9.956 \AA$; c, $3.0215 \AA$; V, $138.56 \AA^{3}$; JCPDS card 17-536). Therefore, the unit cell of goethite contracts when $\mathrm{Al}$ replaces $\mathrm{Fe}$. The Vegard lines which connect the unit cell edge lengths of goethite and diaspore may be used to predict the change.

Synthetic and natural Al-substituted goethites have been examined to construct calibration curves for the determination of Al substitution by X-ray diffraction. Norrish and Taylor (1961) used d(111) of seven soil goethites and found a reasonably good correlation with chemically determined Al. Schulze (1984) synthesized Al-substituted goethites using several methods at $25^{\circ}$ and $70^{\circ} \mathrm{C}$. He found linear relationships between chemically determined $\mathrm{Al}$ and unit cell edge lengths $\underline{b}$ and $\underline{c}$, whereas $\underline{a}$ varied considerably and was higher than the Vegard rule predicted. Because $\underline{\mathrm{b}}$ vs. mol- $\% \mathrm{Al}$ showed some scattering above $20 \mathrm{~mol}-\%$ substitution, Schulze (1984) recommended $\underline{\mathrm{c}}$ for the estimation of Alsubstitution, based on the empirical formula: mol$\% \mathrm{Al}=1730-572.0 \underline{\mathrm{c}}\left(\mathrm{r}^{2}=0.98, \mathrm{n}=81\right)$.

Schulze (1984) noticed that the a dimension of goethites varied with the experimental conditions; those synthesized at $25^{\circ} \mathrm{C}$ had larger a dimensions than those synthesized at $70^{\circ} \mathrm{C}$. The $\underline{b}$ and $\underline{c}$ dimensions were also sensitive to the experimental conditions of goethite formation. The main factors seemed to be the rate of crystallization and temperature - slowly and "hotter" formed goethites had less structural defects and somewhat smaller unit cells (perhaps because of smaller $\underline{\text { a }}$ dimension) than those which had the same degree of substitution but were formed at faster rates.

In Fig. 1, the unit cell edge lengths and the unit cell volume of 32 lake ore goethite samples are plotted against their chemically determined Alsubstitution. During the work it became apparent that different lines gave variable results. Schulze 

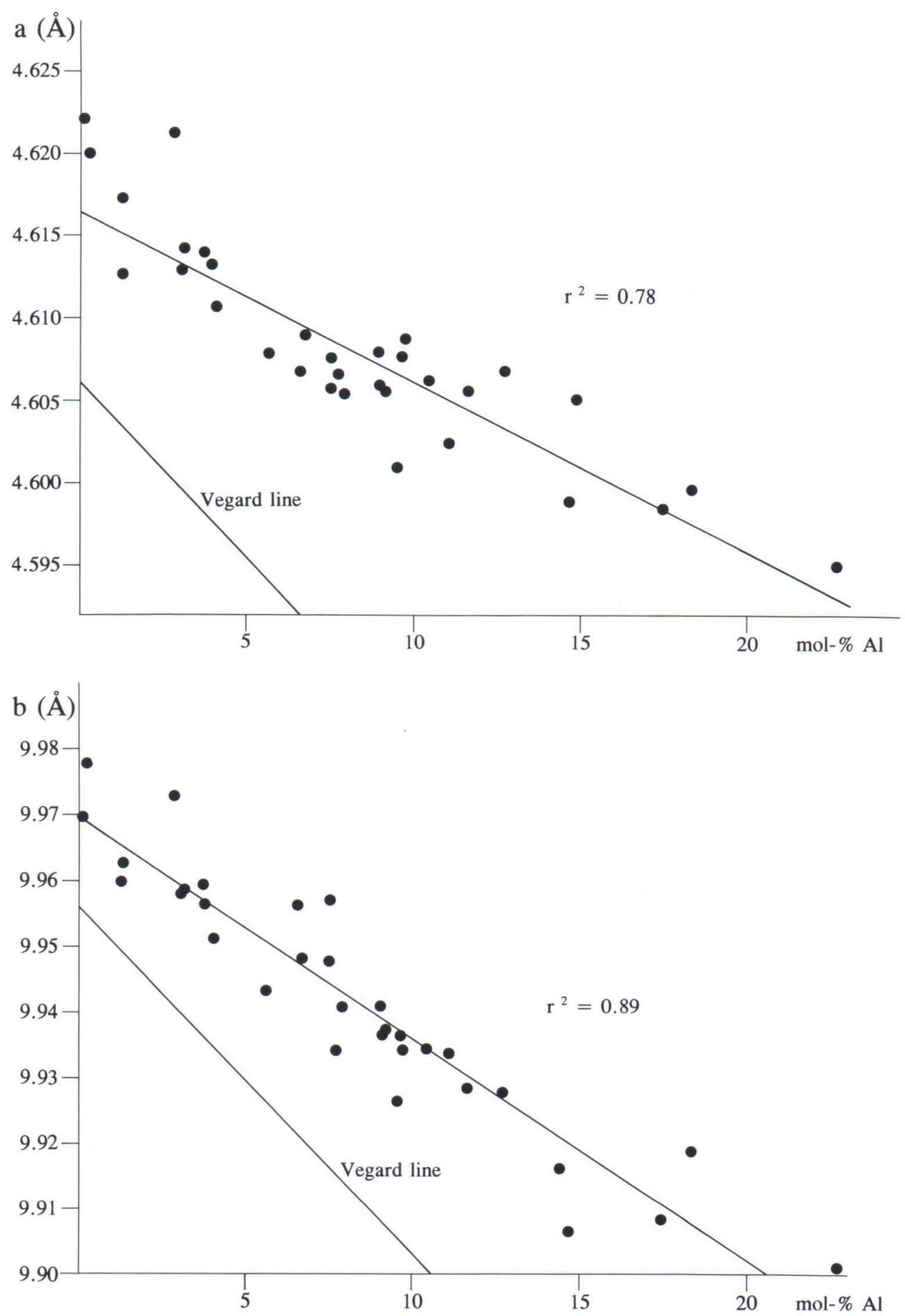

Fig. 1. Relationship of the unit-cell edge lengths $\underline{a}, \underline{b}$, and $\underline{c}$ and the unit cell volume $V$ with the chemically determined Al-substitution for goethites from lake ores. 

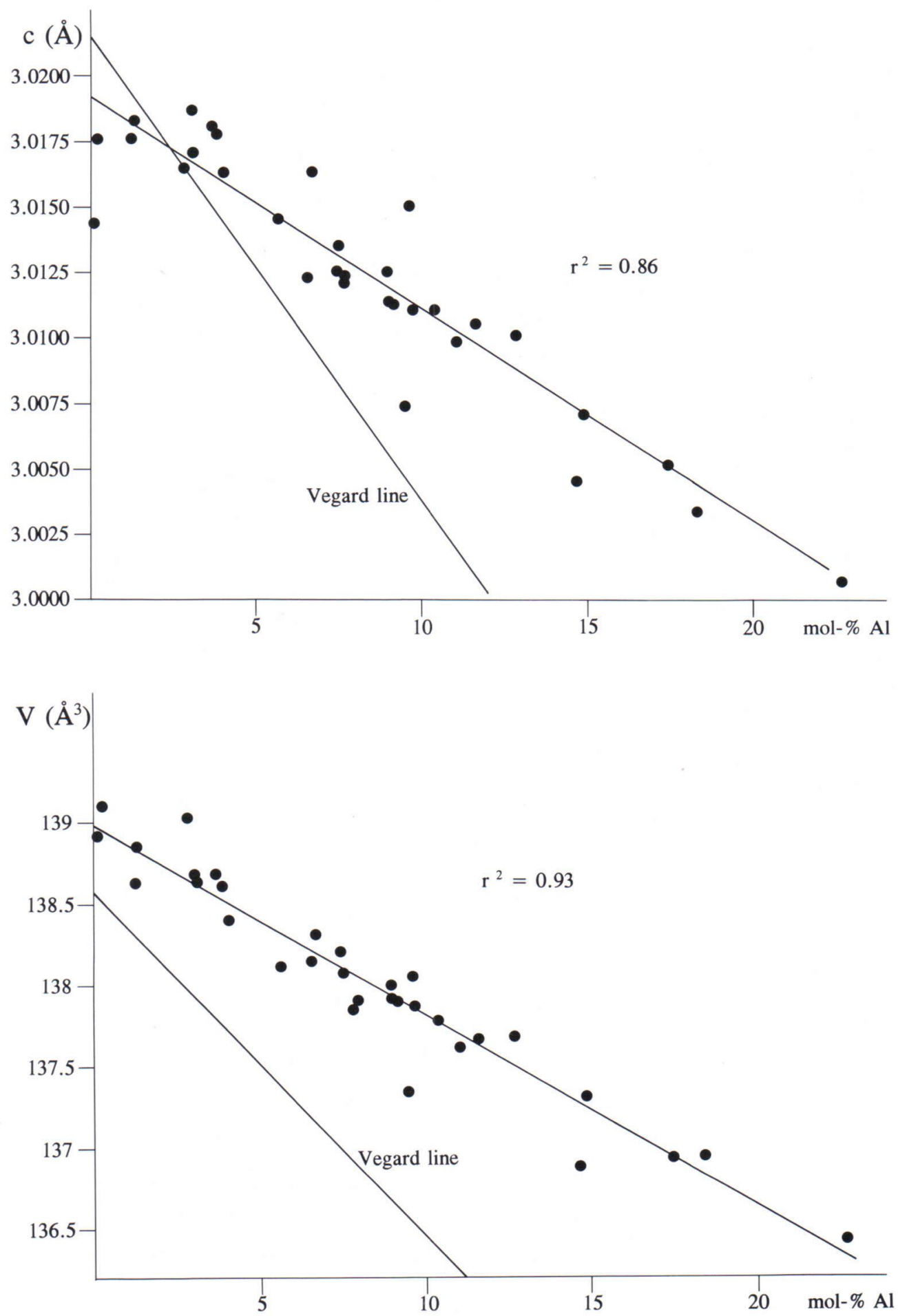
Table 3. Unit cell edge lengths and unit cell volume of lake-ore goethites.

\begin{tabular}{|c|c|c|c|c|c|}
\hline Sample $^{\mathrm{a}}$ & Al mol-\% & $\underline{\mathrm{a}} \AA$ & $\underline{b} \AA$ & $\underline{c} \AA$ & $\vee \AA^{3}$ \\
\hline 101sp1-2 & 14.65 & 4.5990 & 9.9066 & 3.0046 & 136.89 \\
\hline 101sp3-5 & 9.13 & 4.6057 & 9.9374 & 3.0130 & 137.90 \\
\hline 101di5-7 & 9.01 & 4.6060 & 9.9364 & 3.0134 & 137.91 \\
\hline 101di10-13 & 6.69 & 4.6091 & 9.9482 & 3.0163 & 138.31 \\
\hline 102di6-9 & 8.98 & 4.6081 & 9.9409 & 3.0126 & 138.00 \\
\hline 103di12 & 7.77 & 4.6067 & 9.9341 & 3.0121 & 137.84 \\
\hline $107 s p 1-3$ & 22.67 & 4.5952 & 9.9010 & 3.0007 & 136.53 \\
\hline 109Asp4 & 3.72 & 4.6139 & 9.9594 & 3.0181 & 138.68 \\
\hline 109Adi6-8 & 3.12 & 4.6142 & 9.9585 & 3.0171 & 138.64 \\
\hline 109Bsp2-5 & 3.06 & 4.6129 & 9.9581 & 3.0187 & 138.67 \\
\hline 109Bdi6-7 & 3.87 & 4.6133 & 9.9564 & 3.0178 & 138.61 \\
\hline 109Bdibr & 1.23 & 4.6127 & 9.9599 & 3.0176 & 138.63 \\
\hline $109 \mathrm{Cdi5}-7$ & 4.05 & 4.6107 & 9.9512 & 3.0163 & 138.40 \\
\hline $111 \mathrm{sp} 2-7$ & 5.63 & 4.6079 & 9.9434 & 3.0145 & 138.12 \\
\hline $111 \mathrm{cr}$ & 1.28 & 4.6174 & 9.9627 & 3.0182 & 138.84 \\
\hline $114 \mathrm{cr}$ & 2.84 & 4.6212 & 9.9729 & 3.0164 & 139.02 \\
\hline 39Dsp5-8 & 0.11 & 4.6221 & 9.9696 & 3.0144 & 138.91 \\
\hline 39Ddi12-14 & 0.25 & 4.6200 & 9.9777 & 3.0176 & 139.10 \\
\hline 46Csp1-3 & 11.62 & 4.6057 & 9.9280 & 3.0106 & 137.66 \\
\hline 46Csp5-8 & 7.48 & 4.6077 & 9.9568 & 3.0125 & 138.21 \\
\hline 46Cdi4-7 & 9.62 & 4.6077 & 9.9370 & 3.0151 & 138.05 \\
\hline K84sp1-2 & 18.31 & 4.5973 & 9.9189 & 3.0033 & 136.95 \\
\hline K84sp3-6 & 9.50 & 4.6011 & 9.9263 & 3.0074 & 137.35 \\
\hline K84sp6-10 & 7.93 & 4.6055 & 9.9408 & 3.0121 & 137.90 \\
\hline K84cr & 7.50 & 4.6059 & 9.9478 & 3.0135 & 138.07 \\
\hline K87sp1-3 & 17.44 & 4.5986 & 9.9086 & 3.0054 & 136.94 \\
\hline K87sp3-6 & 11.06 & 4.6025 & 9.9336 & 3.0099 & 137.61 \\
\hline K87di12-14 & 6.56 & 4.6068 & 9.9562 & 3.0123 & 138.16 \\
\hline 49Csp3-5 & 10.38 & 4.6063 & 9.9344 & 3.0110 & 137.78 \\
\hline 49Cdi6-8 & 9.71 & 4.6088 & 9.9343 & 3.0113 & 137.87 \\
\hline 49Dsp2-3 & 14.88 & 4.6052 & 9.9164 & 3.0071 & 137.32 \\
\hline 49Ddi5-7 & 12.71 & 4.6068 & 9.9276 & 3.0104 & 137.68 \\
\hline
\end{tabular}


(1984) used three lines (110, 130, and 111) and corrected their positions according to apparent line shift caused by small particle size (broad diffraction lines). The lines were not corrected in the present study because the necessary data were not available for lines at angles above $50^{\circ} 2 \Theta \mathrm{CoK} \alpha$. The widths of the lines used for the calculations were reasonably similar for all specimens.

The unit cell edge lengths showed linear relationships with $\mathrm{Al}$-substitution (Fig. $1 \mathrm{a}-\mathrm{c}$ ). The $\underline{b}$ dimension showed greatest linear dependency $\left(r^{2}=0.89\right)$ and the a dimension the lowest $\left(r^{2}=\right.$ $0.78)$. All values were above those predicted by the Vegard rule. The unit cell volume $\left(r^{2}=0.93\right)$ showed the best linear relationship wit Alsubstitution (Fig. 1 d), also reported previously by Schwertmann et al. (1987). Goethites formed rapidly on sandy or gravelly bottom $(39 \mathrm{D}, 114)$ showed most deviation from the regression lines.

There is a need for calibration curve for XRD determination of Al substitution in natural goethites. There is no calibration curve which suits to goethites formed in all kinds of conditions, rapidly or slowly, in the presence or absence of inhibitors, in cool or warm climate. Unit cell volume has proved to be a better choise than any of the three unit cell edge lengths for lake-ore goethites. Of unit cell edge lengths, $\underline{b}$ seems to be a better choice than $\underline{c}$. This is in line with Schulze's (1984) observation that scattering in $\underline{b}$ dimension occurred above 20 mol-\% substitution which is not relevant in case of lake-ore goethites. According to Schwertmann and Carlson (1994) goethites formed in tropical climates have shorter $\underline{a}$ and $\underline{c}$ dimensions and a smaller unit cell volume than lake-ore goethites but about the same $\underline{b}$ dimension.

ACKOWLEDGEMENTS: Financial support for this study was provided by Deutsche Forschungsgemeinschaft, the Academy of Finland, and the Emil Aaltonen Foundation. The XRD-runs and the computing of the data were performed at the Lehrstuhl für Bodenkunde, Technische Universität München. I thank Prof. U. Schwertmann for facilities, many helpful discussions and comments on the manuscript. With the equipment set at my disposal by my former employer, Department of Geology, University of Helsinki, all these samples would have been classified as X-ray amorphous. Dr. Antti Vuorinen, Department of Geology, University of Helsinki is acknowledged for co-operation in sampling, as is Mr. Kaj Lång, and in analytical work, and Dr. Tapio Koljonen (Geological Survey of Finland) and Mr. Juhani Suksi (Department of Radiochemistry, University of Helsinki) for supplying samples for this study. Dr. Olli H. Tuovinen (Department of Microbiology, The Ohio State University) kindly revised the text.

\section{REFERENCES}

Aarnio, B. (1917) Järvimalmit eräissä Pusulan, Pyhäjärven, Lopen, Someroniemen ja Tammelan järvissä. Geoteknillisiä tiedonantoja 20, 11-61.

Alhonen, P., Koljonen, T., Lahermo, P., and Uusinoka, $R$. (1975) Ferruginous concretions around root channels in clay and fine sand deposits. Bulletin of the Geological Society of Finland 47, 175-181.

Aschan, O. (1908) Humusämnerna i de nordiska inlandsvatten och deras betydelse, särskildt vid sjömalmernas daning. Bidrag till kännedom af Finlands natur och folk, 141-169.

Burns, R.G. and Brown, B.A. (1972) Nucleation and mineralogical controls on the composition of manganese nodules. In: Horn, D.R. (ed.), Ferromanganese Deposits on the Ocean Floor. Office for IDOE/NSF, Washington, D.C., 51-62.

Carlson, L. and Schwertmann, U. (1981) Natural ferrihydrites in surface deposits from Finland and their association with silica. Geochimica et Cosmochimica Acta 45, 421-429.

Carlson, L. and Schwertmann, U. (1987) Iron and manganese oxides in Finnish ground water treatment plants. Water Research 21, 165-170.

Carlson, L., Koljonen, T., Lahermo, P., and Rosenberg,

R.J. (1977) Case study of a manganese and iron precipitate in a ground-water discharge in Somero, southwestern Finland. Bulletin of the Geological Society of Finland 49, 159-173.

Fitzpatrick, R.W. and Schwertmann, U. (1982) Alsubstituted goethite - an indicator of pedogenic and other weathering environments in South Africa. Geoderma 27, 335-347. 
Halbach, P. (1976) Mineralogical and geochemical investigations on Finnish lake ores. Bulletin of the Geological Society of Finland 48, 33-42.

Hatva, T., Seppänen, H., Vuorinen, A., and Carlson, L. (1985) Removal of iron and manganese from groundwater by re-infiltration and slow sand filtration. Aqua Fennica 15, 211-225.

Janik, L.M. and Raupach, M. (1977) An iterative, leastsquares program to separate infrared absorption spectra into their component bands. CSIRO, Division of Soils, Technical Paper 35, 1-37.

Jauhiainen, E. (1969) On soils in the boreal coniferous regions. Fennia 98 (5). Geographical Society of Finland. Helsinki, 123 pp.

Koljonen, T., Lahermo, P., and Carlson, L. (1976) Origin, mineralogy and chemistry of manganiferous and ferruginous precipitates found in gravel and sand deposits in Finland. Bulletin of the Geological Society of Finland 48, 111-135.

Mehra, O.P. and Jackson, M.L. (1960) Iron oxide removal from soils and clays by a dithionite-citrate system buffered with sodium bicarbonate. In:Swineford, A. (ed.), Clays and Clay Minerals, Proceedings of the 7th National Conference, Washington D.C., 1958. Pergamon Press, New York, 317-327.

Moenke-Blankenburg, L., Jahn, K., and Brügmann, $L$. (1989) Laser-micro-analytical studies on distribution patterns of manganese, iron and barium in $\mathrm{Fe} / \mathrm{Mn}$ accumulates of the western Baltic Sea. Chemie der Erde 49, 39-46.

Moore, E.J. (1910) The occurrence and origin of some bog iron deposits in the district of Thunder Bay, Ontario. Economic Geology 5, 528-537.

Norrish, K. and Taylor, R.M. (1961) The isomorphous replacement of iron by aluminium in soil goethites. Journal of Soil Science 12, 294-306.

Nowlan, G.A., McHugh, J.B., and Hessin, T.D. (1983) Origin of concretionary $\mathrm{Mn}$-Fe-oxides in stream sediments of Maine, U.S.A. Chemical Geology 38, 141156.

Schoettle, M. and Friedman, G.M. (1971) Fresh water iron-manganese nodules in Lake George, New York. Geological Society of America Bulletin 82, 101-110.

Schulze, D.G. (1984) The influence of aluminum on iron oxides. VIII. Unit-cell dimensions of Al-substituted goethites and estimation of $\mathrm{Al}$ from them. Clays and Clay Minerals 32, 36-44.
Schwertmann, U. (1964) Differenzierung der Eisenoxyde des Bodens durch Extraktion mit AmmoniumoxalatLösung. Zeitschrift für Pflanzenernährung, Düngung und Bodenkunde 105, 194-202.

Schwertmann, U. (1988) Goethite and hematite formation in the presence of clay minerals and gibbsite at $25^{\circ} \mathrm{C}$. Soil Science Society of America Journal 52, 288-291.

Schwertmann, U. and Carlson, L. (1994) Aluminum influence on iron oxides: Part XVII. Unit-cell parameters and aluminum substitution of natural goethites. Soil Science Society of America Journal 58, 256-261.

Schwertmann, U. and Fitzpatrick, R.W. (1977) Occurrence of lepidocrocite and its association with goethite in Natal soils. Soil Science Society of America Journal 41, 1013-1018.

Schwertmann, U. and Taylor, R.M. (1989) Iron oxides. In: Dixon, J.B. and Weed, S.B. (eds), Minerals in Soil Environmerıts. Soil Science Society of America, Madison, WI, 379-438.

Schwertmann, U., Carlson, L., and Murad, E. (1987) Properties of iron oxides in two Finnish lakes in relation to the environment of their formation. Clays and Clay Minerals 35, 297-304.

Strakhov, N.M. (1966) Types of manganese accumulation in present-day basins: their significance in understanding of manganese mineralization. International Geology Review 8, 1172-1196.

Suess, E. and Djafari, D. (1977) Trace metal distribution in Baltic Sea ferromanganese concretions: inferences on accretion rates. Earth and Planetary Science Letters $35,49-54$.

Taylor, R.M. and Schwertmann U. (1974) The association of phosphorus with iron in ferruginous concretions. Australian Journal of Soil Research 12, 133-145.

Vaasjoki, O. (1956) On the natural occurrence of manganese in Finland. In: Gonzales Reyna, J. (ed.), Proceedings of the 20th International Geological Congress, Symposium on Manganese, 51-62.

Winterhalter, B. and Siivola, J. (1967) An electron microprobe study of the distribution of iron, manganese, and phosphorus in concretions from the Gulf of Bothnia, Northern Baltic Sea. Comptes Rendus de la Societe geologique de Finlande 39, 161-172. 